\title{
Alternative means of recycling pineapple leaf residues
}

Osumanu H. Ahmed*, Ahmad M.H. Husni, Rahin A. Anuar, Mohamed M. Hanafi

Department of Land

Management, University Putra Malaysia, 43400 Serdang,

Selangor, Malaysia osman60@hotmail.com
${ }^{*}$ Correspondence and reprints

Fruits, 2003, vol. 58, p. 53-60 (C) 2003 Cirad/EDP Sciences All rights reserved DOI: $10.1051 /$ fruits:2002036

RESUMEN EsPañol, p. 60

\section{An alternative means of recycling pineapple leaf residue.}

Abstract - Introduction. One of the challenges of the Malaysian pineapple industry is to develop new techniques for managing pineapple residues. A study was carried out to investigate whether K-humate can be produced from these residues. Materials and methods Pineapple leaves were air-dried, shredded and chipped. Some of the shredded leaves were incinerated at $500{ }^{\circ} \mathrm{C}$. Potassium hydroxide $(\mathrm{KOH})$ was extracted by dissolving the ash obtained in distilled water for $24 \mathrm{~h}$ at a ratio of 1:7 (ash / water) after which the sample was filtered. After this extraction of $\mathrm{KOH}$ from the ashes of pineapple leaf residues, the remaining ash residues were further analyzed to assess the total and soluble $\mathrm{K}$ contents. Moreover, a given quantity of shredded leaf residues was mixed with chicken dung (as a source of microorganisms and nitrogen) and chicken feed. The mixture was composted with standard procedures. Humic acids were reconstituted using $\mathrm{KOH}$ from pineapple leaves with $\mathrm{K}$ from ash residues and $\mathrm{K}$ from composted pineapple leaves. Results and discussion. By reconstituting humic acids with $\mathrm{KOH}$, a K-humate was produced with approximately $34.5 \%$ of its $\mathrm{K}$ readily soluble in water. A reconstitution of humic acids with $\mathrm{K}$ from ash residues produced a $\mathrm{K}$-humate with approximately $3.34 \%$ of its $\mathrm{K}$ readily soluble in water. Conclusion. The $\mathrm{K}$-humate produced from the reconstitution of humic acids with $\mathrm{K}$ from $\mathrm{KOH}$ can be used in fertigation programmes as a source of $\mathrm{K}$ while the K-humate produced through the reconstitution of humic acids with $\mathrm{K}$ from ash residues can be used as a source of $\mathrm{K}$ for fresh water fishes.

Malaysia / Ananas comosus / crop residues / leaves / composts / potassium hydroxide / potassium / humic acids

\section{Réutilisation des résidus de feuille d'ananas.}

Résumé - Introduction. En Malaisie, l'un des défis de l'industrie de l'ananas est de développer de nouvelles techniques pour gérer les résidus de cette culture. Une étude a été effectuée pour étudier si de l'acide humique riche en potassium (K-humate) pouvait être produit à partir de ces résidus. Matériel et méthodes. Des feuilles d'ananas ont été séchées à l'air, déchiquetées puis émiettées. Certaines de ces feuilles déchiquetées ont été incinérées à $500{ }^{\circ} \mathrm{C}$. De l'hydroxyde de potassium $(\mathrm{KOH})$ a été extrait en dissolvant la cendre obtenue dans de l'eau distillée (rapport de 1:7, cendre : eau) pendant $24 \mathrm{~h}$, après quoi l'échantillon a été filtré. Après cette extraction de $\mathrm{KOH}$ à partir de résidus incinérés de feuille d'ananas, les résidus de cendre restants ont été analysés pour évaluer la teneur en potassium totale et soluble. Par ailleurs, une quantité donnée de résidus de feuilles déchiquetées a été mélangée à du fumier de poule (comme source de micro-organismes et d'azote) et à de la nourriture pour volaille. Le mélange a été composté en utilisant des procédures standard. Des acides humiques ont été reconstitués à partir du $\mathrm{KOH}$ issus des feuilles d'ananas en utilisant du $\mathrm{K}$ issu des résidus de cendre et du $\mathrm{K}$ issu des feuilles d'ananas compostées. Résultats et discussion. En reconstituant des acides humiques à partir de $\mathrm{KOH}$, de l'acide humique riche en potassium a été obtenu avec approximativement $34,5 \%$ de son $\mathrm{K}$ aisément soluble dans l'eau. Une reconstitution d'acides humiques avec du $\mathrm{K}$ issu des résidus de cendre a produit un " K-humate " avec approximativement 3,34 \% de son K aisément soluble dans l'eau. Conclusion. Le "K-humate " produit à partir de la reconstitution d'acides humiques avec du $\mathrm{K}$ issu de $\mathrm{KOH}$ peut être employé dans des programmes où le potassium doit être apporté en fertigation, alors que le "K-humate " produit par reconstitution d'acides humiques avec du K issu de cendre de résidus peut être employé comme source de K pour des poissons d'eau douce.

Malaisie / Ananas comosus / résidu de récolte / feuille / compost / hydroxyde de potassium / potassium / acide humique 


\section{Introduction}

In Malaysia, about $13 \mathrm{t} \cdot \mathrm{ha}^{-1}$ of pineapple residues are produced on peat each growing season; without an effective and efficient way of handling them, these residues are simply burnt before planting the next crop. Open burning not only reduces the quantity of the valuable organic matter added to the soil but also produces a large quantity of gases such as carbon dioxide which are implicated in ozone depletion. In 1997, fires and haze outbreak across Southeast Asia cost Malaysia about 321 million US\$ [1]. Furthermore, even though as much as $1.31 \mathrm{t} \cdot \mathrm{ha}^{-1}$ ash with a potassium concentration of $17 \%$ is produced from burning pineapple residues, this practice increases neither the uptake of $\mathrm{K}$ significantly nor the crop yield [2]. This has been attributed to a low recovery of $\mathrm{K}$ since, besides early application before planting through burning as compared with fertilizer application $65 \mathrm{~d}$ after planting, the $\mathrm{K}$ uptake in pineapple is generally slow during the early growth period [3]. Thus, due to high rainfall, $\mathrm{K}$ is lost through leaching [2].

One of the challenges of the Malaysian pineapple industry is to develop new techniques for managing pineapple residues. Therefore, the ever-increasing awareness about environmental pollution, the need for achieving sustainable agricultural development and the continuous increase in fertilizer price call for alternative techniques for managing this valuable resource. One of the possible ways of achieving this objective is to develop value-added product(s) from pineapple residues. This can be achieved by producing potassium hydroxide $(\mathrm{KOH})$ from pineapple leaf residues, which, in turn, can be used for extracting humic acid from composted pineapple leaf residues for the production of a potassiumrich humic acid called K-humate.

Our study was carried out to investigate whether K-humate can be produced from pineapple leaf residues by reconstituting humic acid extracted from composted pineapple leaf residues using $\mathrm{KOH}$ (from pineapple leaves) with $\mathrm{K}$ from ash residues (after extraction of $\mathrm{KOH}$ from leaves) and $\mathrm{K}$ from $\mathrm{KOH}$ from pineapple leaf residues, respectively.

\section{Materials and methods}

Pineapple leaf residues were collected from the Simpang Rengam Pineapple Estate, Simpang Rengam, Johor. The leaves were air-dried, shredded and chipped using the Briggs and Stratton shredderchipper (Model 135212). Some of the shredded leaves were incinerated at $(300$, $350,400,450$ and 500$)^{\circ} \mathrm{C}$ for $4 \mathrm{~h}$ in a muffle furnace but, because $500{ }^{\circ} \mathrm{C}$ produced the best ash from the shredded leaves (almost white), this ash at $500{ }^{\circ} \mathrm{C}$ was used throughout this study. The ash was digested using the dry ashing (single dry ashing) method. The $\mathrm{K}$ concentration in solution was determined using an atomic absorption spectrophometer (AAS).

The $\mathrm{KOH}$ was extracted by dissolving ash in distilled water for $24 \mathrm{~h}$ at a ratio of 1:7 (ash / water, weight / volume basis), after which the sample was filtered through a Whatman filter paper number 2. This ratio was arrived at by analyzing the molarities of a series of ash (shredded leaf residue incinerated at $500{ }^{\circ} \mathrm{C}$ ) to distilled water ratios of $1: 5,1: 6,1 ; 7,1: 8,1: 9$, and 1:10. The ash to distilled water ratio of 1:7 was chosen because the ratio produced approximately a $0.1 \mathrm{M} \mathrm{KOH}$ solution for the extraction of humic substances [4]. The method of acid-base titration was used to confirm this concentration. The $0.1 \mathrm{M} \mathrm{KOH}$ solution obtained (not the acidified one) was analyzed for $\mathrm{K}, \mathrm{Ca}, \mathrm{Mg}, \mathrm{Na}, \mathrm{Cu}, \mathrm{Zn}, \mathrm{Al}, \mathrm{Fe}$ and Mn using an AAS, and $\mathrm{pH}$ assessed with a $\mathrm{pH}$ meter.

After the extraction of $\mathrm{KOH}$ from the ashes of pineapple leaf residues, the remaining ash residues were further analyzed to assess the total and soluble K contents. Ash residues were oven-dried at $60{ }^{\circ} \mathrm{C}$ until a constant weight was attained. Some of the ash residues were digested for the total $\mathrm{K}$ using the single dry ashing method. For soluble K, we used the method described by Bailey et al. [5]. 
A quantity of $25 \mathrm{~kg}$ of shredded leaf residues was mixed with $1.25 \mathrm{~kg}$ of chicken dung in liquid form (as a source of microorganisms and nitrogen) and $1.25 \mathrm{~kg}$ of chicken feed. The mixture was composted in a composting drum for $28 \mathrm{~d}$. The moisture content of the compost was maintained at (55 to 60$) \%$. The ambient temperature and the compost temperature were measured on a daily basis using a thermometer. The total organic carbon (TOC) of composted and uncomposted pineapple leaf residues was measured by loss of weight on ignition at $550{ }^{\circ} \mathrm{C}$ for $8 \mathrm{~h}$ (organic C calculated as $58 \%$ of the organic matter) [6]. The micro Kjedahl method was used for the determination of the total nitrogen [7] and the leaching method for the determination of the cation exchange capacity (CEC) [8] of the composted and uncomposted leaves. For the extraction and purification of humic acid, the method described by Stevenson [9] was followed.

\section{Results and discussion}

The total $\mathrm{K}$ concentration in the pineapple leaf residues was high (35\%) and was sufficient to produce a $0.1 \mathrm{M} \mathrm{KOH}$ solution. This high $\mathrm{K}$ concentration may be due to the naturally high $\mathrm{K}$ content in pineapple leaves $[2,3]$. By incinerating the pineapple leaf residues, a unit weight of pineapple leaf residue ash will naturally be high in $\mathrm{K}$.

The $\mathrm{pH}$ of the $0.1 \mathrm{M} \mathrm{KOH}$ solution was 11.10. The $0.1 \mathrm{M} \mathrm{KOH}$ solution contained $50 \% \mathrm{~K}$ with $\mathrm{Al}, \mathrm{Cu}, \mathrm{Mn}, \mathrm{Zn}, \mathrm{Fe}, \mathrm{Mg}$, Ca and $\mathrm{Na}$ content generally low (table I). From a practical point of view, further purification of the $\mathrm{KOH}$ was not deemed necessary as this would entail some cost which would in turn make the production of this $\mathrm{KOH}$ more expensive. This could possibly be one of the reasons why an analytical grade of $\mathrm{NaOH}$ is preferred to that of an analytical grade of $\mathrm{KOH}$ in humic and fulvic acid extraction. Aside from this, the elements in the $\mathrm{KOH}$ solution obtained from the pineapple leaf residues could be recycled in the form of fulvate, particularly in K-fulvate,

\section{Table I.}

Elemental composition of a $0.1 \mathrm{M} \mathrm{KOH}$ solution $(50 \% \mathrm{~K})$ obtained from pineapple leaf residues.

$\begin{array}{cc}\text { Element } & \begin{array}{c}\text { Content in the } \mathrm{KOH} \text { solution } \\ \left(\mathrm{mg} \cdot \mathrm{kg}^{-1}\right)\end{array} \\ \mathrm{Al} & 2 \\ \mathrm{Cu} & 17 \\ \mathrm{Mn} & 30 \\ \mathrm{Zn} & 40 \\ \mathrm{Fe} & 80 \\ \mathrm{Mg} & 120 \\ \mathrm{Ca} & 300 \\ \mathrm{Na} & 1300\end{array}$

after the extraction of humic acid or K-humate (salt of humic acid).

During the composting process, three typical phases of composting were observed by temperature measurements (figure 1). There was a mesophilic phase during the first $2 \mathrm{~d}$ in which the temperature rose to $46^{\circ} \mathrm{C}$. At this mesophilic stage, the predominant microbes are the mesophilic bacteria [10]. At this time, the abundance of readily available and easily digestible substrate (e.g., sugars, starches, simple protein compounds, etc.) might have ensured that the microorganisms were very active, leading to the generation of large quantities of metabolic heat energy, which caused the temperature of the compost to increase.

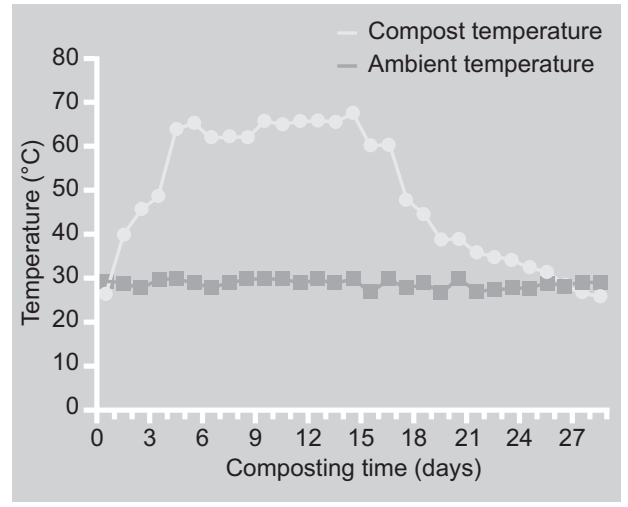

Figure 1.

Ambient and compost temperature measured at different times during the composting of pineapple leaf residues. 
The second stage was a thermophilic phase lasting for $15 \mathrm{~d}$ in which the temperature increased to a maximum of $67.3^{\circ} \mathrm{C}$. As the temperature rose past $46^{\circ} \mathrm{C}$, conditions were less favorable for the mesophilic bacteria and instead began to favor the thermophilic bacteria, mostly Bacillus species [11] that play a major role in the decomposition of proteins and other carbohydrate compounds [12]. The resulting increased microbial activity of the thermophiles caused the temperature in the compost to rise to $67.3^{\circ} \mathrm{C}$. Further temperature increases were avoided by turning and, mixing the compost once every $2 \mathrm{~d}$, and after $28 \mathrm{~d}$ of composting, the compost temperature equaled that of the ambient temperature.

Eventually, with the depletion of the food sources, overall microbial activity decreased and the temperature fell, resulting in a second mesophilic phase during the cooling stage. As the readily available microbial food supply was consumed, the temperature fell to ambient and the material entered a maturation stage and, during this stage, the microbial activity was low [10]. The phases described were similar to the results previously reported by several researchers during the composting process [6, 13-16].

The change in CEC [17], ash content [6] and the $\mathrm{C} / \mathrm{N}$ ratio $[6,14,18]$ reflects organic matter decomposition and stabilization of a compost. The ash content increased from the initial value of $7 \%$ for the uncomposted leaves to $23 \%$ for the composted leaves. The CEC of the compost, a measure of the capacity of the compost to hold exchangeable cations such as $\mathrm{K}, \mathrm{Ca}, \mathrm{Mg}$ and $\mathrm{Na}$ to

Figure 2.

Relationship between the amount of soluble $\mathrm{K}$ released from ash residues (after extraction of $\mathrm{KOH}$ from pineapple leaf residues) with equilibration time. negatively charged surfaces of the compost (e.g., $\mathrm{OH}, \mathrm{COOH}$, when dissociated) also increased from an initial value of (32 to 68.32) $\mathrm{cmol} \cdot \mathrm{kg}^{-1}$. The high CEC of the compost indicates that the organic material of the compost has become more humified [19]. The carbon to nitrogen (C/N, weight/ weight basis) ratio decreased from an initial value of 38.30 to a final value of 11.58 . The $[\mathrm{C} / \mathrm{N}]$ ratio of 11.58 found for the composted pineapple leaf residues in this study compared well with the ratio of 12 reported by Chefetz et al. [6]. The ratio also fell within the $[\mathrm{C} / \mathrm{N}]$ ratio of 10 to 12 usually considered to be an indicator of stable and decomposed organic matter [14]. The humic acid increased from $2.77 \%$ in the uncomposted leaf residues to $20 \%$ in the composted leaf residue.

The total and soluble $\mathrm{K}$ of the ash residue were (18 and 8.34)\%, respectively. There was a negative significant relationship between the amount of soluble $\mathrm{K}$ released from the ash residue (after extraction of $\mathrm{KOH}$ ) with equilibration time (figure 2). The highest release occurred a day after equilibration followed by a successive decrease with time, indicating that the highest amount of soluble $\mathrm{K}$ that can be released from the ash residue after extraction of $0.1 \mathrm{M} \mathrm{KOH}$ occurs within a day and does not exceed approximately $8.34 \% \mathrm{~K}$ even if allowed to stand for one week.

In order to make use of this ash residue, humic acid was reconstituted with $\mathrm{K}$ from the ash residue using a humic acid to ash residue ratio of 10:1 (weight basis), and equilibrated in $40 \mathrm{~mL}$ distilled water. There was a significant negative relationship between the amount of $\mathrm{K}$ adsorbed at the exchange complex (perhaps $\mathrm{COOH}$, phenolic $\mathrm{OH}$, etc.) of the humic acid with time (figure 3). A day after equilibration in distilled water, there was a general decrease in the adsorption of $\mathrm{K}$, indicating that the maximum adsorption does not go beyond $1 \mathrm{~d}$. It seems that the general decline in the soluble $\mathrm{K}$ of the ash residue observed in figure 2 partly explains this observation, as a decrease in soluble $\mathrm{K}$ led to a decrease in the amount of $\mathrm{K}$ adsorption, and this association was found to be significant (figure 4). It is interesting to note that 
approximately $3.34 \% \mathrm{~K}$ was in the humic acid, and this amount is sufficient to support the $\mathrm{K}$ requirement of fresh water fishes.

Fresh water contains less than $10 \mathrm{mg} \mathrm{K} \cdot \mathrm{L}^{-1}$ [20]. According to the studies of Shearer [21], inadequate levels of dietary $\mathrm{K}$ supply for the young king salmon (a fresh water fish) resulted in poor feed intake and feed utilization as well as growth retardation when the diet contained less than $1 \mathrm{mg} \mathrm{K} \cdot \mathrm{L}^{-1}$, and increased mortality also occurred. A maximum growth was obtained at a dietary level of $8 \mathrm{~g} \mathrm{~K} \cdot \mathrm{kg}^{-1}$ dry diet, while whole-body concentrations were normal at 6-12 $\mathrm{g} \mathrm{K} \cdot \mathrm{kg}^{-1}$ diet [21]. Besides, the backbone of K-humate, which is humic acid, can stimulate the growth of organisms such as phytoplanktons and algae [22], diatoms and dinoflagellates [23]. These organisms play an important role in the food chain of fishes. It is believed that humic acids stimulate the growth of these organisms by chelating and solubilizing micronutrient metal ions that otherwise would be present in an insoluble or colloidal form. Furthermore, $\mathrm{N}$ and $\mathrm{P}$ directly from humic acids enhance growth of these organisms [23]. Excessive levels of $\mathrm{Cu}$ are toxic to fishes [24] and a study conducted by Florence et al. [25] has indicated that humic substances may be effective in ameliorating the toxicity of hydrophobic $\mathrm{Cu}$ complexes in fresh water.

The relatively low amount of $\mathrm{K}$ displaced (3.34\%) may be partly attributed to the low acid strength $(\mathrm{pKa}=15.7)$ of water which in this case served as the conjugate acid of the humic acid salt (K-humate) [26]. Almost all the $\mathrm{K}$ in the salt seemed to have been displaced from the exchange sites (carboxylic and phenol) [26] when the salt was acidified with dilute $\mathrm{HCl}$ before purification to obtain humic acid (figure 5) for the onward reconstitution with $\mathrm{K}$.

One of the variables that is used to assess the quality of fresh waters for fresh water fishes is $\mathrm{pH}$, and the available literature has shown that waters with $\mathrm{pH}$ near neutral $(7 \pm 1)$ [27] or a $\mathrm{pH}$ range of 6.5 to 9 are likely to be suited to good fish production [28]. The $\mathrm{pH}$ of the K-humate

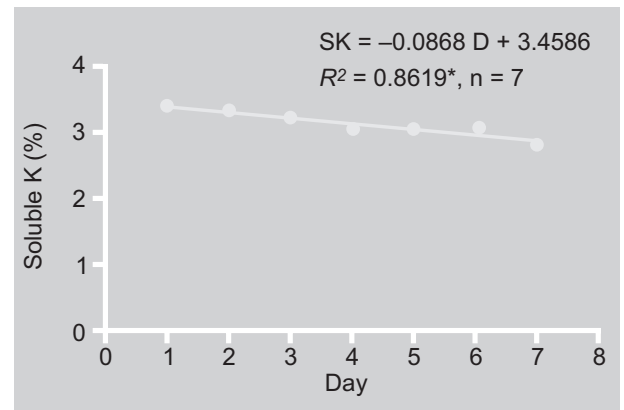

Figure 3.

Absorption of soluble K (SK) release by humic acids, from ash residue remaining after extraction of $\mathrm{KOH}$ from pineapple leaf residues.

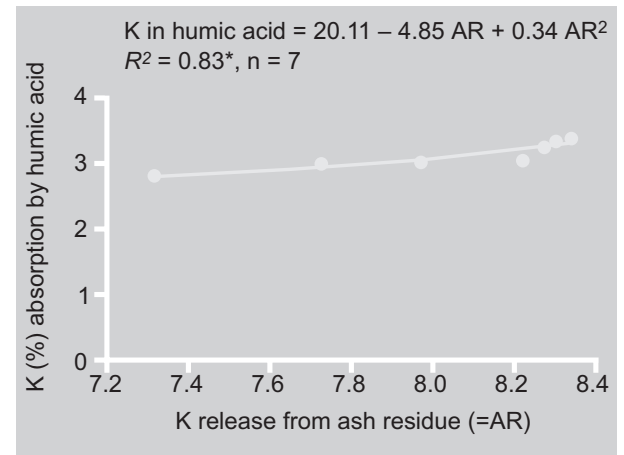

Figure 4.

Relationship between soluble $\mathrm{K}$ released from ash residue remaining after extraction of $\mathrm{KOH}$ from pineapple leaf residues and absorption by humic acid.

was 6.7, which is consistent with the $\mathrm{pH}$ of fresh waters that support fresh water fish production.

In terms of a $\mathrm{K}$ source for agricultural use, the amount of $\mathrm{K}$ in the reconstituted humic acid, as noted in the preceding discussion, is relatively low. As a means of increasing the $\mathrm{K}$ content in humic acids, purified humic acids were reconstituted with $\mathrm{K}$ using humic acid to $0.1 \mathrm{M} \mathrm{KOH}$ (derived from an incinerated pineapple leaf residue) ratios (weight to volume basis) of 1:5, 1:10, 1:15, 1:20, 1:25 and 1:30 (table II). Ratios below 1:5 were excluded because of the lack of complete dissolution of humic acid in the $\mathrm{KOH}$. The adsorption of $\mathrm{K}$ at the

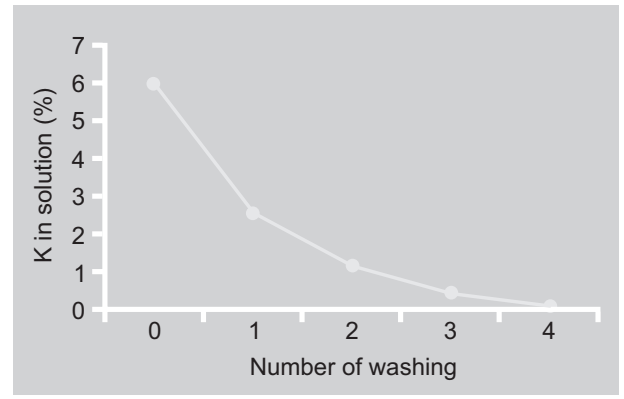

Figure 5

Effect of washing on $\mathrm{K}$ removal from humic acid extracted from composted pineapple leaf residues. 
Table II.

Potassium content and $\mathrm{pH}$ of humic acid (K-humate) reconstituted with a $0.1 \mathrm{M} \mathrm{KOH}$ solution produced from pineapple leaf residues using different humic acid to $0.1 \mathrm{M} \mathrm{KOH}$ solution ratios.

\begin{tabular}{ccc}
\hline K-humate & $\mathrm{K}(\%)$ & $\mathrm{pH}$ \\
\hline Humic acid only & Trace & 2.20 \\
$1: 5$ & 25 & 9.80 \\
$1: 10$ & 32.15 & 10.33 \\
$1: 15$ & 32.95 & 10.53 \\
$1: 20$ & 34.54 & 10.80 \\
$1: 25$ & 38.10 & 10.80 \\
$1: 30$ & 38.12 & 10.82 \\
\hline
\end{tabular}

exchange sites of the humic acids generally increased with the increasing ratios but it leveled off after 1:20, indicating that the succeeding ratios contained a sufficient amount of $\mathrm{K}$ to saturate the exchange sites of the humic acids with. A similar trend was observed for $\mathrm{pH}$ except that the leveling off started at 1:20 (table II), probably due to the presence of the inherent cations such as $\mathrm{Na}, \mathrm{Ca}$ and $\mathrm{Mg}$ in the $\mathrm{KOH}$. Considering the amount of $\mathrm{K}$ in the $\mathrm{K}$-humate and the $\mathrm{pH}$, coupled with the fact that the K-humate readily dissolves in water, the possibility of using liquid $\mathrm{K}$-humate as a source of $\mathrm{K}$ for fertigation or hydroponics is worth detailed exploration.

A sub-irrigation study was conducted on a poor quality soil formed on a lithological substrate of loam; irrigation water treated with humic acid extracted from sewerage sludge compost revealed that, besides increasing plant yield, the addition of humic substances stimulated the absorption of nitrogen and potassium by lucerne plants [29]. This means that, in a fertigation program, apart from serving as potassium carrier, the backbone of K-humate, which in this case is humic acid, could stimulate or facilitate the absorption of $\mathrm{K}$.

\section{Conclusion}

K-humates can be produced from pineapple leaf residue for agricultural use.

\section{Acknowledgements}

We thank Lee Sing Kim, Koh Soo Koon and Faisol Abdul Ghani of the Simpang Rengam Pineapple Estate for their help, the National Council for Scientific Research and Development, Malaysia, for financial support and the staff of the Soil Fertility Laboratory for their analyses.

\section{References}

[1] Mohd Shahwahid H.O., Jamal O., Malaysia, in: Glover D., Jessup T. (Ed.), The Indonesia's fires and haze: the catastrophe, Inst. Southeast Asia Stud., Singap., Malays., 1999, pp. 22-50.

[2] Ahmed O.H., Husni M.H.A., Syed Omar R.S., Hanafi M.M., Koh S.K., The effects of residue management practices on phosphorus and potassium uptake in pineapple, Malays. J. Soil Sci. 3 (1999) 29-37.

[3] Py C., Lacoeuilhe J.J., Teisson C., The pineapple cultivation and uses. Maisonneuve and Larose (Eds.), Paris, France, 1987.

[4] Gracia D., Cegarra J., Bernal M.P., Navarro A., Comparative evaluation of methods employing alkali and sodium pyrophosphate to extract humic substances from peat, Soil Sci. Plant Anal. 24 (13-14) (1993) 14811494.

[5] Bailey D.A., Nelson P.V., Fonteno W.C., Ji-We On Lee, Jin-Sheng, Breakthrough plug research, $\mathrm{pH}$, fertilization and nutrition, Floracult. Int. (January) (1996) 18-19.

[6] Chefetz B., Hatcher P.G., Hadar Y., Chen Y., Chemical and biological characterization of organic matter during composting of municipal solid waste, J. Environ. Qual. 25 (1996) 776-785.

[7] Bremner J.M., Total nitrogen, in: Methods of Soil Analysis, Part 2, Black C.A. (Ed.), Am. Soc. Agron., Madison, Wis., USA, 1965, pp. 1149-1170.

[8] Cottenie A., Soil and plant testing as a basis of fertilizer recommendations, FAO Soils Bull. 38/2, 1980, $100 \mathrm{p}$.

[9] Stevenson F.H., Humus chemistry: genesis, composition, reactions (2nd ed.), John Wiley and Sons Inc., New York, USA, 1994. 
[10] Day M., Shaw K., Biological, chemical, and physical processes of composting, in: Stoffella P.J., Kahn B.A. (Eds.), compost utilization in horticultural cropping systems, Lewis Publishers, Boca Raton, USA, 2000, pp. $17-50$.

[11] Strom P.F., Identification of thermophilic bacteria in solid-waste composting, Appl. Environ. Microbiol. 50 (1985) 906-913.

[12] Polprasert C., Organic waste recycling: technology and management (2nd ed.), John Wiley and Sons Ltd., Chichester, UK, 1996.

[13] Dalzell H.W., Biddlestone A.J., Gray K.R., Thurairajan K., Soil management: compost production and use in tropical and subtropical environments, FAO, Rome, Italy, FAO Soils Bull., 56, 1987, 177 p.

[14] Jimenez E.I., Gracia V.P., Determination of maturity indices for city refuse composts, Agr. Ecosyst. Environ. 38 (1992) 331-343.

[15] Inbar Y., Chen Y., Hadar Y., Recycling of cattle manure: the composting process and characterization of maturity, J. Environ. Qual. 22 (1993) 857-863.

[16] Mulyadi, Potassium dynamics and availability from composted and uncomposted rice straw, thesis, Univ. Putra Malays., Malays., 2000.

[17] Harada Y., Inoko A., Tadaki M., Izadaki T., Maturing process of city refuse compost during piling, Soil Sci. Plant Nutr. 27 (1981) 357-364.

[18] Chanyasak V., Hirai M., Kubota H., Changes of chemical components and nitrogen transformation in water extracts during composting of garbage, J. Ferment. Technol. 60 (1982) 439-446.

[19] Sullivan D.M., Miller R.O., Compost quality attributes, measurements, and variability, in: Stoffella P.J., Kahn B.A. (Eds.), Compost uti- lization in horticultural cropping systems, Boca Raton, USA, Lewis Publishers, 2000, pp. 95-120.

[20] Steffens W., Principles of fish nutrition, Ellis Horwood Ltd., Chichester, West Sussex, UK, 1989.

[21] Shearer K.D., Dietary potassium requirement of juvenile chinook salmon, Aquaculture 73 (1988) 119-129.

[22] Lee Y.S., Bartlett R.J., Stimulation of plant growth by humic substances, Soil Sci. Soc. Am. J. 40 (1976) 876-879.

[23] Prakash A., Rashid M.A., Jensen A., Rao D.V.S., Influence of humic substances on the growth of marine phytoplankton: diatoms, Limnol, Oceanogr. 18 (1973) 516-524.

[24] Martyshev F.G., Pond fisheries, Russian Translation Series, Vysshaya Shkola Publ., Moscow, Russia, 1991.

[25] Florence T.M., Powell H.K.J., Stauber J.L., Town R.M., Toxicity of lipid-soluble copper (II) complexes to the marine diatom Nitzschia closterium: amelioration by humic substances, Water Res. 26 (2) (1992) 11871193.

[26] Johnson A.W., Invitation to organic chemistry, Jones and Bartlett Publ., Boston, USA, 1999.

[27] Landau M., Introduction to aquaculture, John Wiley and Sons Inc., New York, USA, 1992.

[28] Brown E.E., Gratzek J.B., Fish farming handbook, Van Nostrand Reinhold, New York, USA, 1980.

[29] Gracia C., Hernandez T., MorenoJ.L., Pascual J.A., Roldan A., Use of wastewater and humic substances extracted from sewage sludge compost in subirrigation, in: Humic substances downunder: understanding and managing organic matter in soils, sediments and waters, Proc. 9th Int. Meet. Int. Humic Subst. Soc., Adel., Aust., 1998, 259 p. 


\section{Reutilización de los residuos de hoja de piña.}

Resumen - Introducción. En Malasia, uno de los retos de la industria de la piña es desarrollar nuevas técnicas para el manejo de los residuos de este cultivo. Se efectuó un estudio para estudiar si se podía producir, a partir de estos residuos, ácido húmico rico en potasio (K-humato o humato de potasio). Material y métodos. Se secaron algunas hojas de piña al aire, se despedazaron y, luego, desmenuzaron. Algunas de estas hojas despedazadas fueron incineradas a $500{ }^{\circ} \mathrm{C}$. Se extrajo hidróxido de potasio $(\mathrm{KOH})$ disolviendo la ceniza obtenida en agua destilada (relación de 1:7, ceniza : agua) durante 24 h y, posteriormente, se filtró la muestra. Tras esta extracción de $\mathrm{KOH}$ a partir de residuos incinerados de hoja de piña, los residuos de ceniza restantes se analizaron para evaluar el contenido en potasio total y soluble. Por otra parte, se mezcló una cantidad dada de residuos de hojas despedazados con estiércol de gallina (como fuente de microorganismos y nitrógeno) y con comida para aves. La mezcla se compostó utilizando procedimientos estándar. Se reconstituyeron ácidos húmicos a partir del $\mathrm{KOH}$ procedente de las hojas de piña utilizando el K procedente de los residuos de ceniza y el $\mathrm{K}$ procedente de las hojas de piña compostadas. Resultados y discusión. Al reconstituir ácidos húmicos a partir del $\mathrm{KOH}$, se obtuvo ácido húmico rico en potasio con aproximadamente un $34,5 \%$ de su $\mathrm{K}$ fácilmente soluble en el agua. Una reconstitución de ácidos húmicos con $\mathrm{K}$ procedente de los residuos de ceniza produjo un "K-humato" con aproximadamente el 3,34\% de su K fácilmente soluble en agua. Conclusión. El "K-humato" producido a partir de la reconstitución de ácidos húmicos con $\mathrm{K}$ procedente de $\mathrm{KOH}$ puede emplearse en programas en los que el potasio deba aportarse en fertigación, mientras que el "K-humato" producido por reconstitución de ácidos húmicos con K procedente de ceniza de residuos puede emplearse como fuente de $\mathrm{K}$ para pescados de agua dulce.

Malasia / Ananas comosus / residuos de cosechas / hojas / compost / hidróxido de potasio / potasio / ácido húmico

To access this journal online: www.edpsciences.org 